Kemampuan Termos dalam Mempertahankan Suhu Cairan Kristaloid (Ringer Laktat dan Normal Saline 0,9\%) : Sebuah Alternatif untuk Menjaga Suhu Cairan Resusitasi

\title{
Thermos Ability in Maintaining Crystalloid Liquid Temperature (Ringer's Lactate and Normal Saline 0,9\%): an Alternative in Maintaining Resuscitation Fluid Temperature
}

Ninda Saputri ${ }^{1}$, Abdurrahman Wahid ${ }^{2}$, Tina Handayani Nasution ${ }^{3}$, Gia Eka Negara ${ }^{4}$

1,2,3Ilmu Keperawatan, Universitas Lambung Mangkurat

${ }^{4}$ Fisika, Universitas Lambung Mangkurat

*Korespondensi penulis:

Abdurrahman Wahid

Ilmu Keperawatan, Universitas Lambung Mangkurat

Jl. A Yani KM 26, Banjarbaru, Telp: (0511)4772745

Email: ns.wahid@ulm.ac.id

\section{Info Artikel \\ Riwayat Artikel: \\ Dikirim 31 Mei 2021 \\ Direvisi 24 Agustus 2021 \\ Diterima 13 September 2021}

\section{Kata Kunci:}

Syok hemoragik

Ringer laktat

Normal saline $0,9 \%$

Termos

Suhu.

\begin{abstract}
ABSTRAK
Penanganan syok hemoragik dengan terapi cairan yang bersuhu $39^{\circ} \mathrm{C}$ merupakan rekomendasi untuk mencegah terjadinya hipotermi. Penyimpanan cairan infus di dalam termos nasi merupakan salah satu metode untuk menjaga suhu cairan infus. Penelitian ini bertujuan untuk mengetahui pengaruh penggunaan termos untuk mempertahankan suhu $39^{\circ} \mathrm{C}$ cairan kristaloid (ringer laktat dan normal saline $0,9 \%$ ) pada suhu ruang $25^{\circ} \mathrm{C}$. Metode peneliti ini menggunakan kuantitatif eksperimental (pra-eksperimental) dengan jenis rancangan one-shot case study. Enam botol cairan ringer laktat dan enam botol cairan normal saline $0,9 \%$ dihangatkan sampai $39^{\circ} \mathrm{C}$, kemudian disimpan di termos nasi di ruang bersuhu $25^{\circ} \mathrm{C}$ dan diukur perubahan suhunya selama 6 jam. Pengukuran dilakukan dengan menggunakan termometer digital. Data dianalisis dengan uji Mann Whitney. Penelitian dilakukan pada tanggal 1 Desember 2019. Hasil penelitian menunjukkan penurunan suhu cairan ringer laktat rata-rata $4,6^{\circ} \mathrm{C}$ dan normal saline $0,9 \%$ rata-rata $4,3^{\circ} \mathrm{C}$. Ada perbedaan perubahan suhu yang signifikan pada cairan ringer laktat dan normal saline $0,9 \%$ $(p=0,000 ; \alpha=0,05)$. Hasil dari penelitian adalah termos nasi mampu mempertahankan suhu cairan ringer laktat $39{ }^{\circ} \mathrm{C}$ selama 96 menit dan normal saline $0,9 \%$ selama 78 menit, sedangkan untuk mencegah hipotermi $\left(36^{\circ} \mathrm{C}\right)$ cairan ringer laktat selama 4 jam 59 menit dan normal saline $0,9 \%$ selama 4 jam 55 menit.
\end{abstract}

Keywords:

Hemorrhagic shock

Ringer lactate

Normal saline 0,9\%

Thermos

Temperature

\section{ABSTRACT}

Haemorrhagic shock should be treated with fluid therapy at $390^{\circ} \mathrm{C}$ to avoid hypothermia. Storage of infusion fluid in a rice thermos is one method to maintain the temperature of the infusion fluid. This study aimed to determine the effect of using a thermos to maintain a temperature of $39^{\circ} \mathrm{C}$ crystalloid liquid (ringer lactate and normal saline 0,9\%) at a room temperature of $25^{\circ} \mathrm{C}$. This research method uses experimental quantitative (pre-experimental) with a one-shot case study design. Six bottles of Ringer's lactate and six bottles of normal saline 0,9\% were warmed to $39^{\circ} \mathrm{C}$, then stored in a rice thermos at $25^{\circ} \mathrm{C}$ and the temperature changes were measured for 6 hours. A digital thermometer was used to take measurements. The Mann-Whitney test was used to analyze the data. The results show that the temperature of Ringer's lactate fluid was reduced by an average of $4,6^{\circ} \mathrm{C}$, and normal saline was reduced by an average of $4,3^{\circ} \mathrm{C}$. There was a significant difference in temperature changes in the ringer's lactate fluid and normal saline $0,9 \%(p=0,000 ; \alpha=0,05)$. The results of the study were that the rice thermos was able to maintain the temperature of ringer's lactate fluid at $39^{\circ} \mathrm{C}$ for 96 minutes and normal saline 0,9\% for 78 minutes, while to prevent hypothermia $\left(36^{\circ} \mathrm{C}\right)$ ringer's lactate fluid for 4 hours 59 minutes and normal saline 0,9\% for 4 hours 55 minutes. 


\section{Pendahuluan}

Syok Hemoragik banyak disebabkan oleh trauma yang diperoleh dari kecelakaan lalu lintas (Agus D, Aryana I G N W, 2017). Laporan data 2013, jumlah korban meninggal dunia di seluruh dunia mencapai 1,25 juta orang akibat kecelakaan lalu lintas (Hardoko E, 2018). Perdarahan dalam jumlah sedikit ataupun banyak dapat menyebabkan syok hipovolemik dan bahkan kematian (Aldo Y, Nova E S, 2015). Pendarahan yang sebagian besar terjadi pada pasien trauma berkaitan erat dengan kematian yang cepat terjadi (Tanaka C, Wiargitha K, Golden N, 2018). Penanganan syok hemoragik sesuai prinsip fisiologi dasar yaitu melakukan terapi cairan (Lewis S R, Pritchard M W, Evans D J W, Butler A R, Alderson P, Smith A F, Roberts I, 2018). Cairan kristaloid yang digunakan untuk mengganti cairan atau darah yang hilang dari tubuh bisa berupa normal saline $0,9 \%$ atau ringer laktat karena bersifat fisiologis dan isotonis (Jane L, Ian D N, 2016).

Sebuah kejadian klinis menunjukkan komplikasi pasca trauma pada pasien dengan suhu tubuh inti kurang dari $32^{\circ} \mathrm{C}$ dilaporkan mencapai angka kematian hingga 100\% (Mommpen P, Zeckey C, Frink M, Krettek C, Hildebrand F, 2012). Pemberian terapi cairan paling efisien dalam mencegah terjadinya hipotermi adalah cairan bersuhu $39{ }^{\circ} \mathrm{C}$ $\left(102,2^{\circ} \mathrm{F}\right.$ ) (Stewart R M, 2018) (Singleton W, et al, 2017) (Yanala U R, Johanning J M, Pipinos I I, High R R, Larsen G, Velander W H, Carlson M A, 2018). Apabila hipotermi terjadi, maka dapat memicu dan memperburuk koagulopati yaitu keadaan darah tidak membeku secara normal (Tanaka C, Wiargitha K, Golden N, 2018) (Stewart R M, 2018).

Chamber dan Heater yang merupakan sistem pemanas yang dirancang oleh sarjana Program Studi Fisika, Universitas Lambung Mangkurat, Indonesia terbukti dapat memanaskan cairan infus. Chamber dan Heater telah lulus uji verifikasi di Balai Kalibrasi dan Sertifikasi Mutu Barang, Banjarbaru, Indonesia serta tertelusur ke SI (Satuan Internasional). Namun, alat Chamber dan Heater bekerja dengan memberikan kalor terus menerus, sehingga tidak dapat digunakan untuk mempertahankan cairan infus di suhu $39{ }^{\circ} \mathrm{C}$. Penelitian terhadap metode atau alat yang efektif untuk mempertahankan suhu cairan infus $39{ }^{\circ} \mathrm{C}$ diperlukan untuk mencegah hipotermia saat diberikan kepada pasien dengan Syok Hemoragik. Peneliti memilih alat berupa termos karena termos didesain kedap udara dan memiliki penutup yang bersifat adiabatik. Bahan adiabatik menghambat interaksi antara sistem di dalam termos dan lingkungan luar sehingga suhu cairan infus di dalamnya dapat dipertahankan (Yulkifli, Usmeldi, Yohandri, Anggreini, 2017).

Suhu ruangan atau suhu kamar di Indonesia adalah antara $20-25{ }^{\circ} \mathrm{C}$ (Wirawan I M C, 2017). Paparan suhu lingkungan luar termos yang dipilih adalah suhu ruangan yang paling mendekati suhu cairan infus yaitu suhu ruangan tertinggi sebesar $25^{\circ} \mathrm{C}$. Suhu $25{ }^{\circ} \mathrm{C}$ dipilih agar hasil penelitian berupa waktu maksimal cairan infus bertahan pada suhu 39 ${ }^{0} \mathrm{C}$.

Jumlah cairan kristaloid dipilih berdasarkan perhitungan kelas III syok hemoragik (kehilangan darah $2.000 \mathrm{ml}$ ). Syok hemoragik kelas III dipilih karena di tahap tersebut adalah saat transfusi darah ataupun terapi cairan sangat fatal jika tidak diberikan, sama halnya dengan syok hemoragik kelas IV. Syok hemoragik kelas IV tidak dipilih untuk menjadi acuan jumlah cairan infus yang digunakan karena, syok hemoragik kelas IV sudah pada tahap respon tubuh mengalami gagal fungsi organ, sehingga kematian sangat mungkin terjadi. Pada kasus syok hemoragik kelas III, jika ditangani dengan terapi cairan maka digunakan nilai 3:1, sehingga diperlukan 6 liter cairan atau 12 botol cairan kristaloid (enam botol ringer laktat dan enam botol normal saline 0,9\%) (Anwar F, 2017). Untuk itu, peneliti tertarik melakukan penelitian agar mengetahui pengaruh penggunaan termos dalam mempertahankan suhu $39{ }^{\circ} \mathrm{C}$ cairan kristaloid (ringer laktat dan normal saline $0,9 \%$ ) pada suhu ruang $25{ }^{\circ} \mathrm{C}$.

\section{Metode}

Penelitian ini menggunakan desain penelitian kuantitatif eksperimental (pra- 
eksperimental) dengan jenis rancangan oneshot case study. Penelitian ini dinyatakan bebas etik penelitian oleh Komite Etik Penelitian Fakultas Kedokteran Universitas Lambung Mangkurat karena, tidak menggunakan subjek hidup baik manusia, hewan, maupun tumbuhan. Penelitian menggunakan enam botol cairan ringer laktat $500 \mathrm{~mL}$ dan enam botol cairan normal saline $0,9 \%$. Enam botol cairan ringer laktat berukuran $500 \mathrm{~mL}$ dan enam botol cairan normal saline $0,9 \%$ berukuran $500 \mathrm{~mL}$ dihangatkan sampai $39{ }^{\circ} \mathrm{C}$ menggunakan alat pemanas yang dirancang oleh sarjana Program Studi Fisika, Universitas Lambung Mangkurat, Indonesia. Alat pemanas terdiri dari:

1. Sistem pemanas yaitu chamber atau tempat penampung cairan ringer laktat dan normal saline $0,9 \%$ dan heater yang digunakan dengan daya aliran listrik.

2. Alat ukur temperatur yang telah dilakukan uji verifikasi dengan cara membandingkan temperatur yang terbaca oleh alat buat dengan alat thermohygrometer yang telah tertelusur ke SI (Satuan Internasional), uji verifikasi sudah dilakukan di Balai Kalibrasi dan Sertifikasi Mutu Barang, Banjarbaru, Indonesia.

3. Sistem akuisisi data yang merupakan sebuah sistem untuk menampilkan data hasil pengukuran pada komputer pribadi (Personal Computer, PC) dan mencatat data hasil pengukuran secara otomatis per satu detik. Sistem akuisisi data dirancang dan diprogram menggunakan software Delphi 7.0.

Salah satu cairan ringer laktat dipilih secara acak untuk dimasukkan termometer digital yang beroperasi dengan sistem akuisisi data agar terpantau kenaikan suhu per detik selama dipanaskan. Enam cairan ringer laktat dipanaskan sampai bersuhu $39{ }^{\circ} \mathrm{C}$. Setelah dipanaskan, enam botol cairan ringer laktat diukur suhunya satu persatu sehingga didapatkan enam data suhu. Salah satu botol cairan ringer laktat yang telah dipilih dengan cara acak sebelumnya, dimasukkan termometer digital kembali untuk memantau penurunan suhu selama penyimpanan di dalam termos nasi. Setelah memasukkan termometer digital ke dalam salah satu botol cairan ringer laktat, enam botol cairan ringer laktat bersuhu $39{ }^{\circ} \mathrm{C}$ disimpan di dalam satu termos nasi berukuran 14 liter dan dipaparkan pada suhu $25{ }^{\circ} \mathrm{C}$ selama 6 jam. Perlakuan yang sama juga diterapkan pada enam botol cairan normal saline $0,9 \%$.

Dalam penelitian ini menggunakan dua buah termos nasi untuk menyimpan cairan infus yang telah dipanaskan. Tidak ada jenis cairan infus berbeda yang disimpan dalam satu termos nasi. Cairan infus dimasukkan ke dalam termos nasi plastik tanpa menggunakan aliran listrik. Selama penelitian berlangsung, perubahan suhu diukur setiap detiknya menggunakan termometer digital sebanyak dua buah yang sebelumnya telah dimasukkan satu ke dalam botol cairan ringer laktat yang telah dipilih secara acak, dan satu ke dalam botol cairan normal saline $0,9 \%$ yang dipilih secara acak.

Setelah 6 jam penyimpanan cairan infus ringer laktat dan normal saline $0,9 \% \mathrm{di}$ dalam termos nasi, semua botol cairan infus ringer laktat dan normal saline diukur suhunya. Data dibandingkan antara suhu cairan ringer laktat dan normal saline 0,9\% setelah dipanaskan dan setelah disimpan di dalam termos nasi dengan paparan suhu ruang $25{ }^{\circ} \mathrm{C}$. Data kemudian juga dianalisis dengan uji Mann Whitney.

\section{Hasil dan Pembahasan}

\section{Perubahan suhu cairan kristaloid ringer laktat dan normal saline $0,9 \% 39^{\circ} \mathrm{C}$ di dalam termos yang dipaparkan di suhu ruang $2^{\circ} \mathrm{C}$}

Hasil pengukuran suhu cairan ringer laktat $39{ }^{\circ} \mathrm{C}$ di dalam termos nasi yang dipaparkan suhu ruangan ber $A C$ dengan pengaturan suhu $A C$ sebesar $25{ }^{\circ} \mathrm{C}$ selama 6 jam ternyata tidak stabil. Hasil pengukuran suhu ruangan selama penelitian diukur menggunakan termometer digital yaitu $25 \pm 1$ ${ }^{\circ} \mathrm{C}$. Dengan perlakuan tersebut, didapatkan data suhu cairan ringer laktat yang dipilih dimasukkan termometer digital menurun sebesar $4,5{ }^{\circ} \mathrm{C}$, digambarkan pada grafik di bawah ini. 


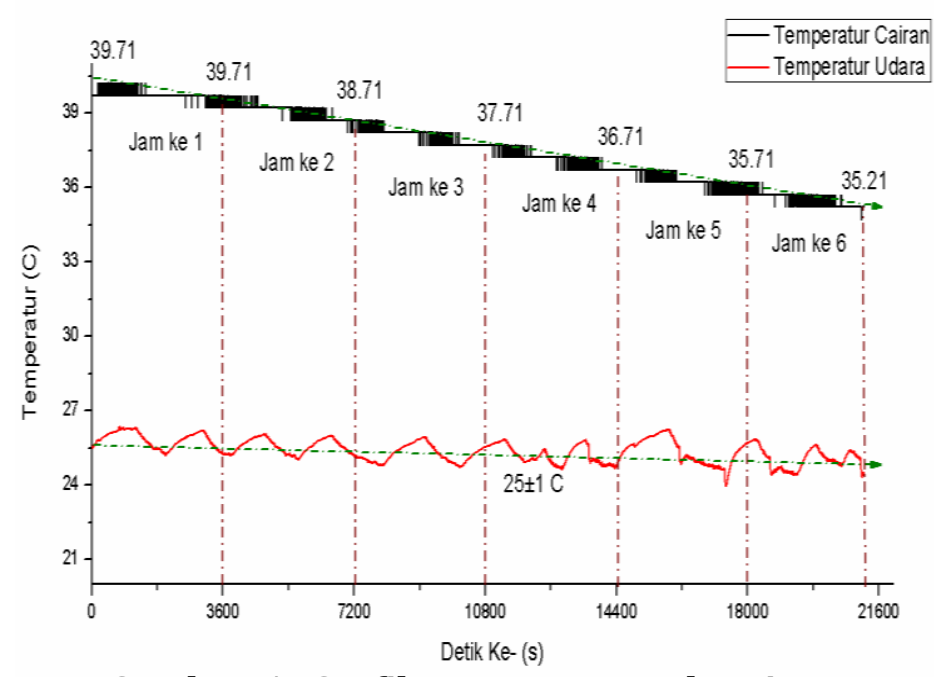

Gambar 1. Grafik penurunan suhu ringer laktat per jam

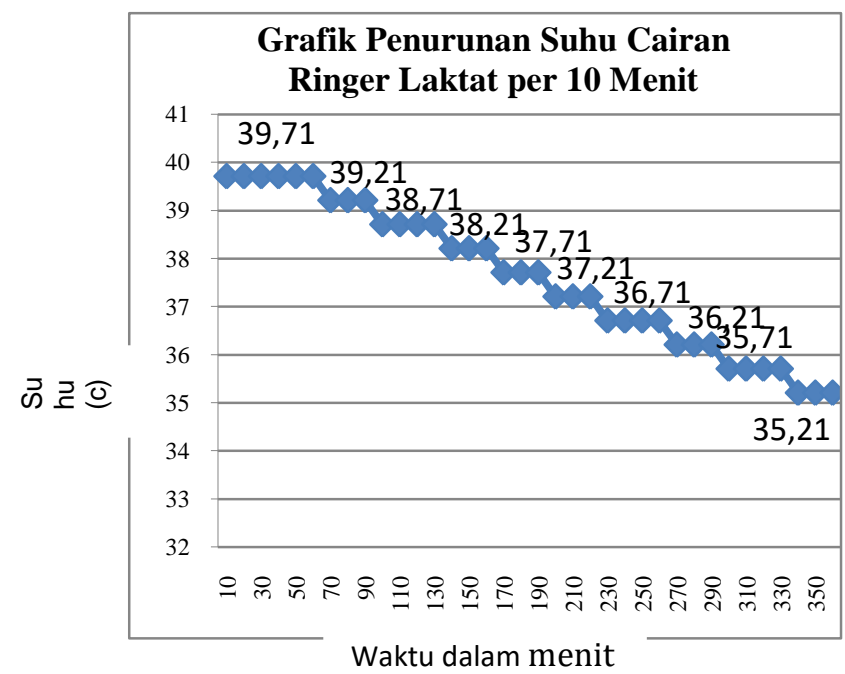

Gambar 2. Grafik penurunan suhu cairan ringer laktat per 10 menit

Setelah 6 jam cairan ringer laktat disimpan di dalam termos nasi berukuran 14 liter dengan paparan suhu ruangan ber AC 25 ${ }^{0} \mathrm{C}$, semua cairan dikeluarkan dari termos nasi. Kemudian enam botol cairan ringer laktat diukur distribusi perubahan suhunya. Hasil pengukuran adalah rentang perubahan suhu enam botol cairan ringer laktat menurun sebesar 4,5- 4,8 ${ }^{\circ} \mathrm{C}$. Rincian perubahan suhu setiap cairan ringer laktat pada tabel di bawah ini.
Tabel 1. Penurunan 6 buah cairan RL yang ditempatkan pada termos selama 6 jam, dengan suhu ruang $25 \pm 1^{\circ} \mathrm{C}$

Cairan Temperatu Temperatu Penurunan $\begin{array}{llll}\text { RLke- } & \mathrm{r} \text { Awal } & \mathrm{r} & \left({ }^{\circ} \mathrm{C}\right)\end{array}$ $\left({ }^{\circ} \mathrm{C}\right)$

Akhir Akhir $\left({ }^{0} \mathrm{C}\right)$

\begin{tabular}{llll}
\hline 1 & 39,7 & 35,2 & 4,5 \\
\hline 2 & 39,7 & 35,0 & 4,7 \\
\hline 3 & 39,8 & 35,1 & 4,7 \\
\hline 4 & 39,8 & 35,0 & 4,8 \\
\hline 5 & 39,5 & 35,0 & 4,5 \\
\hline 6 & 39,5 & 35,0 & 4,5 \\
\hline
\end{tabular}

Selama penelitian, salah satu cairan normal saline $0,9 \%$ dipilih secara acak untuk dimasukkan termometer digital dan mendapatkan perlakuan disimpan di dalam termos nasi dan dipaparkan suhu ruangan 25 $\pm 1^{\circ} \mathrm{C}$ selama 6 jam. Cairan normal saline $0,9 \%$ yang dipilih suhu nya menurun sebesar $4,4{ }^{\circ} \mathrm{C}$ yaitu dari suhu $39,8{ }^{\circ} \mathrm{C}$ menjadi $35,4{ }^{\circ} \mathrm{C}$. Penurunan suhu cairan normal saline 0,9\% yang dipilih digambarkan pada grafik di bawah ini.

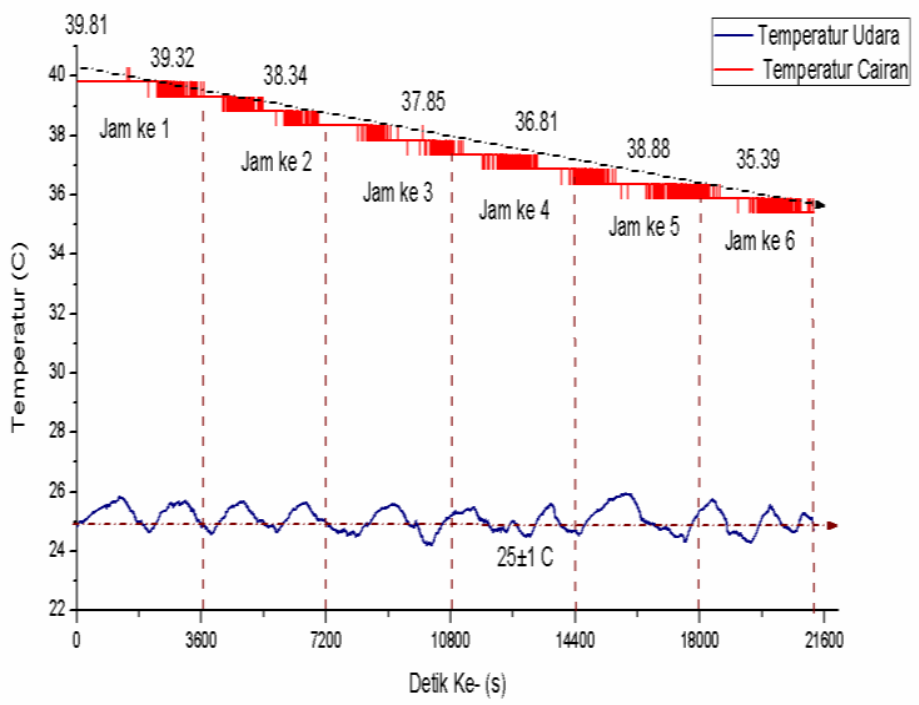

Gambar 3. Grafik penurunan suhu cairan normal saline $0,9 \% 25{ }^{\circ} \mathrm{C}$ 


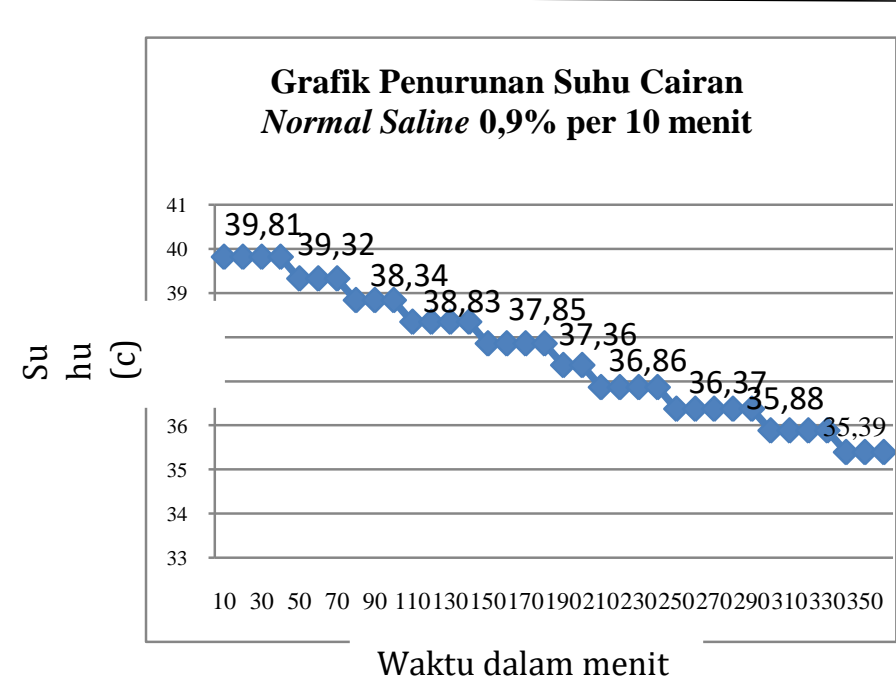

Gambar 4. Grafik penurunan suhu cairan normal saline $0,9 \%$ per 10 menit

Cairan infus bersuhu $39^{\circ} \mathrm{C}$ yang telah disimpan di dalam termos nasi dan dipaparkan suhu ruangan $25 \pm 1^{\circ} \mathrm{C}$ selama 6 jam kemudian dikeluarkan dari termos nasi. Cairan yang telah dikeluarkan dari termos nasi diukur distribusi perubahan suhunya. Hasil perubahan enam botol cairan normal saline $0,9 \%$ adalah menurun $4,2-4,5{ }^{\circ} \mathrm{C}$. Perubahan suhu setiap cairan normal saline 0,9 \% tersebut dituliskan pada tabel di bawah ini.

Tabel 2. Penurunan 6 buah cairan NS 0,9\% yang ditempatkan pada termos selama 6 jam, dengan suhu ruang $25 \pm 1^{\circ} \mathrm{C}$

\begin{tabular}{|c|c|c|c|}
\hline $\begin{array}{c}\text { Cairan } \\
\text { NS } \\
\text { NS } \\
0,9 \% \\
\text { ke- }\end{array}$ & $\begin{array}{l}\text { Temperatur } \\
\text { Awal } \\
\left({ }^{\circ} \mathrm{C}\right)\end{array}$ & $\begin{array}{c}\begin{array}{c}\text { Temperatur } \\
\text { akhir }\end{array} \\
\text { Akhir } \\
\left.{ }^{\circ} \mathrm{C}\right)\end{array}$ & $\begin{array}{c}\text { Penurunan } \\
\left({ }^{\circ} \mathrm{C}\right)\end{array}$ \\
\hline 1 & 39,8 & 35,4 & 4,2 \\
\hline 2 & 39,6 & 35,3 & 4,3 \\
\hline 3 & 39,7 & 35,2 & 4,5 \\
\hline 4 & 39,6 & 35,4 & 4,2 \\
\hline 5 & 39,6 & 35,2 & 4,4 \\
\hline 6 & 39,4 & 35,2 & 4,2 \\
\hline
\end{tabular}

Data perubahan suhu cairan kristaloid ringer laktat dan normal saline $0,9 \%$ di dalam termos nasi yang dipaparkan suhu $25 \pm 1{ }^{\circ} \mathrm{C}$ selama 6 jam didapatkan dengan menggunakan termometer digital. Hasil perubahan suhu cairan ringer laktat menurun sebesar 4,5-4,8 ${ }^{\circ} \mathrm{C}$. Sedangkan hasil penurunan suhu cairan normal saline 0,9\% menurun sebesar 4,2-4,5 ${ }^{\circ} \mathrm{C}$. Perubahan suhu dengan jenis cairan yang sama bisa dikatakan homogen, karena dari data penelitian penurunan suhu antar botol dengan jenis cairan yang sama memiliki perbedaan suhu yang sangat sedikit yaitu, $<1{ }^{\circ} \mathrm{C}$.

Penurunan suhu disebabkan oleh perlakuan paparan suhu $25 \pm 1{ }^{\circ} \mathrm{C}$. Paparan suhu $25 \pm 1{ }^{\circ} \mathrm{C}$ menyebabkan perpindahan kalor dari suhu tinggi ke suhu rendah, dalam penelitian ini maka kalor cairan berpindah ke udara lingkungan (Supu I, Usman B, Basri S, Sunarmi, 2016). Perpindahan kalor dari cairan kristaloid ringer laktat dan normal saline 0,9\% relatif terhambat, dikarenakan adanya perlakuan oleh peneliti berupa cairan tersebut disimpan di dalam termos nasi yang terbuat dari bahan plastik. Sebagai bahan yang adiabatik material plastik dianggap cukup baik untuk proses adiabatic. Proses adiabatik adalah proses yang terjadi tanpa adanya perpindahan kalor dalam suatu sistem dan prosesnya berlangsung sangat cepat (Asnawati, Suliyanah, Rohmawati L, 2019).

Hipotermi terjadi ketika suhu inti tubuh kurang dari $35{ }^{\circ} \mathrm{C}$. Suhu $35{ }^{\circ} \mathrm{C}$ termasuk ke dalam kategori hipotermi ringan (NANDA, 2015). Dari definisi hipotermia diatas, diketahui bahwa suhu tubuh normal minimal untuk mencegah kejadian hipotermi adalah 36 ${ }^{0} \mathrm{C}$. Hasil dari penelitian diketahui bahwa cairan normal saline $0,9 \%$ bersuhu $\pm 39{ }^{\circ} \mathrm{C}$ di dalam termos yang dipaparkan pada suhu ruang $25 \pm 1{ }^{\circ} \mathrm{C}$ dapat bertahan di suhu $36^{\circ} \mathrm{C}$ yaitu tepatnya pada suhu $36,37 \pm 0,5{ }^{\circ} \mathrm{C}$ selama 4 jam 55 menit, begitu juga dengan perlakuan yang sama pada cairan ringer laktat yaitu bertahan pada suhu $36,21 \pm 0,5{ }^{\circ} \mathrm{C}$ selama 4 jam 59 menit. Sehingga dapat disimpulkan dengan keadaan lingkungan bersuhu $25 \pm 1{ }^{\circ} \mathrm{C}$ cairan ringer laktat dan normal saline 0,9\% hangat bersuhu $39{ }^{\circ} \mathrm{C}$ yang disimpan pada termos nasi plastik masih dapat digunakan selama hampir 5 jam dan berdampak terhadap pencegahan hipotermi dan komplikasinya.

Suhu ruangan yang dipaparkan pada penelitian tidak bisa menetap pada suhu $25{ }^{\circ} \mathrm{C}$ yaitu $\pm 1^{\circ} \mathrm{C}$, hal tersebut bisa disebabkan oleh 
beberapa faktor diantaranya : 1) Sudut datangnya sinar matahari juga berpengaruh terhadap suhu. Penelitian penurunan suhu cairan kristaloid ringer laktat dan normal saline $0,9 \%$ yang dimasukkan ke dalam termos yaitu pada jam 09.12- 15.12 WITA, sehingga dalam rentang waktu tersebut sudut datangnya matahari berbeda-beda. Semakin tegak sudut datang sinar matahari, maka semakin panas suhu di tempat tersebut, dan berlaku sebaliknya semakin miring datangnya sinar matahari, maka semakin dingin suhu di tempat tersebut (Cahyono T, 2017). Sudut datang matahari yang dapat mengalirkan panas ke dalam ruangan dapat diminimalkan dengan memastikan ruangan yang digunakan pada penelitian terbayangi atau tertutup oleh bangunan lainnya (Budhyowati M Y N, et al, 2016).

Perbandingan perubahan suhu ringer laktat dan normal saline $0,9 \%$ di dalam termos yang dipaparkan di suhu ruang $2^{\circ} \mathrm{C}$

Tabel 3. Perbandingan perubahan suhu ringer laktat dan normal saline $0,9 \%$ di dalam termos yang dipaparkan di suhu ruang $25^{\circ} \mathrm{C}$

\begin{tabular}{lcccc}
\hline $\begin{array}{l}\text { Variabe } \\
\text { l Mean }\end{array}$ & SD & $\begin{array}{l}\text { Min- } \\
\text { Max }\end{array}$ & $\begin{array}{l}\text { p- } \\
\text { value }\end{array}$ \\
\cline { 1 - 4 } Ringer & 37,689 & 1,480 & 34,71 & 0,000 \\
Laktat & 9 & 2 & 40,21 & \\
\cline { 1 - 4 } Normal & 37,658 & 1,390 & 35,39 & \\
Saline & 1 & 9 & 40,31 & \\
$0,9 \%$ & & & & \\
\hline
\end{tabular}

Hasil dari uji normalitas kedua data bernilai sig 0,000 yang menunjukkan data tidak berdistribusi normal, sehingga uji data menggunakan uji Mann Whitney. Hasil uji data dengan Mann Whitney nilai p-value yaitu 0,000 . Nilai tersebut menunjukkan p-value $(0,000)<\alpha(0,05)$ sehingga dapat disimpulkan ada perbedaan suhu yang signifikan pada cairan kristaloid ringer laktat dan normal saline $0,9 \%$. Termos nasi berukuran 14 liter berbahan plastik tanpa daya listrik mampu bertahan untuk mempertahankan suhu ringer laktat $39{ }^{\circ} \mathrm{C}$ tepatnya hingga suhu $39,21{ }^{\circ} \mathrm{C}$ hingga detik ke 5.767 atau sekitar 96 menit pertama, sedangkan untuk mempertahankan suhu cairan normal saline $0,9 \% 39{ }^{\circ} \mathrm{C}$ tepatnya pada suhu $39,32{ }^{\circ} \mathrm{C}$ hingga detik ke 4.573 atau sekitar 78 menit pertama. Sehingga dapat disimpulkan termos berpengaruh dalam mempertahankan suhu $39^{\circ} \mathrm{C}$ cairan kristaloid (ringer laktat dan normal saline 0,9\%).

Hasil dari penurunan suhu cairan kristaloid ringer laktat dan normal saline 0,9\% yang memiliki perlakuan sama memiliki penurunan suhu berbeda yaitu, lebih cepat penurunan pada cairan ringer laktat sebesar $4,5{ }^{\circ} \mathrm{C}$ dibandingkan normal saline $0,9 \%$ yang memiliki penurunan $4,4^{\circ} \mathrm{C}$. Hal tersebut sesuai dengan komposisi di dalam cairan ringer laktat dan normal saline 0,9\% yang berbeda pada jumlah senyawa natrium klorida di dalamnya. Perbedaan jumlah senyawa natrium klorida di dalam cairan ringer laktat dan normal saline 0,9\% yaitu senyawa tersebut lebih banyak terdapat pada cairan normal saline $0,9 \%$ dibandingkan cairan ringer laktat, dengan rincian (Mane A S, 2017):

1) Cairan ringer laktat memiliki natrium sebanyak $130 \mathrm{mmol} / \mathrm{l}$, dan klorida sebanyak $109 \mathrm{mmol} / \mathrm{l}$.

2) Cairan normal saline $0,9 \%$ memiliki natrium sebanyak $154 \mathrm{mmol} / \mathrm{l}$, dan klorida sebanyak $154 \mathrm{mmol} / \mathrm{l}$.

Senyawa yang terlarut di dalam kedua cairan kristaloid membuat titik didih dan titik lebur meningkat. Titik didih $\mathrm{NaCl}$ adalah sebesar $1.465^{\circ} \mathrm{C}$, dan titik lebur atau titik leleh sebesar 800,7 ${ }^{\circ} \mathrm{C}$. Ringer laktat juga mengandung senyawa $\mathrm{NaCl}$ dan tambahan berupa asam laktat yang memiliki titik didih sebesar $122{ }^{\circ} \mathrm{C}$ dan titik lebur sebesar $16,8{ }^{\circ} \mathrm{C}$, serta potassium yang memiliki titik didih $758,8{ }^{\circ} \mathrm{C}$ dan titik lebur sebesar $63,5{ }^{\circ} \mathrm{C}$ (Haynes, William M, et al, 2011).

Dilihat dari titik didih dan titik lebur serta jumlah asam laktat dan $\mathrm{NaCl}$, tentu senyawa $\mathrm{NaCl}$ memiliki posisi dominan dalam meningkatkan titik didih dan titik lebur cairan kristaloid ringer laktat dan normal saline $0,9 \%$. Konsentrasi senyawa terlarut atau yang bisa disebut molalitas kedua cairan dalam penelitian yang lebih besar adalah pada cairan normal saline 0,9\% (Mane A S, 2017). Sesuai teori diketahui bahwa semakin besar molalitas maka semakin besar pula 
penyerapan kalor yang diperlukan untuk meningkatkan suhu suatu larutan (Putri Laili Mei Ari,et al, 2017). Sehingga dapat kita simpulkan dalam keadaan suhu $39{ }^{\circ} \mathrm{C}$ cairan ringer laktat dan normal saline 0,9\%, maka cairan normal saline $0,9 \%$ lah yang mengandung kalor yang lebih banyak.

Perlakuan penyimpanan pada termos yang bersifat adiabatik menyebabkan kalor yang dapat keluar tertahan, dan hanya bisa keluar sedikit demi sedikit (Marscella, Fitri A, 2017). Akibat penempatan cairan kristaloid ringer laktat dan normal saline $0,9 \%$ di dalam sistem yang adiabatik ini menyebabkan pada waktu yang telah ditentukan dalam penelitian ini yaitu 6 jam, tidak banyak kalor yang dapat keluar, dan masih menyisakan kalor yang relatif banyak pada cairan (dilihat dari penurunan suhu yang lebih sedikit dibandingkan suhu yang tersisa), akibat kalor yang berada pada cairan normal saline 0,9\% lebih banyak, maka besar kemungkinan kalor yang tersisa di cairan normal saline 0,9\% selama 6 jam perlakuan juga lebih banyak, sehingga menyebabkan penurunan suhu lebih sedikit dibandingkan cairan ringer laktat.

\section{Manfaat Hasil Penelitian dalam Penyimpanan Cairan Resusitasi \\ Pada proses penelitian diketahui} bahwa terdapat alat pemanas yang bisa dibuat oleh seorang sarjana fisika FMIPA ULM yang tentunya telah terstandar dan efektif digunakan sebagai pemanas cairan infus hingga suhu yang kita inginkan. Hasil penelitian juga didapatkan hasil bahwa termos sebagai alat yang diteliti oleh peneliti bisa digunakan untuk alat penyimpanan cairan kristaloid ringer laktat dan normal saline $0,9 \%$ yang telah dihangatkan dan berfungsi dapat memperlambat penurunan suhu. Hasil dari penelitian ini diharapkan dapat menjadi acuan sebagai penggunaan termos dalam keadaan tertentu. Contohnya pada keadaan bencana yang terdapat pasien dengan kasus syok hemoragik. Dalam keadaan bencana ada beberapa hal yang memungkinkan tempat tersebut terputus daya listriknya, sehingga ketika ingin memberikan resusitasi cairan yang hangat harus di tempat yang masih terdapat daya listrik (karena alat penghangat perlu daya listrik). Selama perjalanan menuju tempat pasien, termos nasi dapat menjadi media penyimpanan cairan infus hangat tersebut dan tetap stabil menjaga suhu walaupun dalam perjalanan mengalami guncangan, selama termos tidak terbuka. Hal yang di atas juga dapat diaplikasikan pada rujukan pasien dengan syok hemoragik yang memerlukan perjalanan menuju rumah sakit rujukan selama \pm 5 jam.

Pemberian cairan kristaloid ringer laktat atau normal saline 0,9\% hangat bersuhu $39{ }^{\circ} \mathrm{C}$ direkomendasikan, karena dengan suhu tersebut dapat mencegah hipotermi yang akhirnya juga mencegah komplikasi hipotermi diantaranya koagulopati (Stewart R M, 2018), henti jantung atau fibrilasi jantung (Hall JE, 2011), risiko perdarahan meningkat, iskemia miokardium, pemulihan pasca anestesi yang lebih lama, gangguan penyembuhan luka, serta meningkatnya risiko infeksi (Harahap, anggita M, Rudi K, Ezra O, 2014). Hipotermi terjadi ketika suhu inti kurang dari $35^{\circ} \mathrm{C}$, dan suhu $35{ }^{\circ} \mathrm{C}$ termasuk ke dalam kategori hipotermi ringan (NANDA, 2015), sehingga suhu tubuh normal minimal untuk mencegah kejadian hipotermi adalah $36^{\circ} \mathrm{C}$. Hasil dari penelitian diketahui bahwa cairan normal saline $0,9 \%$ bersuhu $\pm 39^{\circ} \mathrm{C}$ di dalam termos yang dipaparkan pada suhu ruang $25 \pm 1{ }^{\circ} \mathrm{C}$ dapat bertahan di suhu $36^{\circ} \mathrm{C}$ yaitu tepatnya pada suhu $36,37 \pm 0,5{ }^{\circ} \mathrm{C}$ selama 4 jam 55 menit, begitu juga dengan perlakuan yang sama pada cairan ringer laktat yaitu bertahan pada suhu $36,21 \pm 0,5{ }^{\circ} \mathrm{C}$ selama 4 jam 59 menit. Sehingga dapat disimpulkan dengan keadaan lingkungan bersuhu $25 \pm 1{ }^{\circ} \mathrm{C}$ cairan ringer laktat dan normal saline $0,9 \%$ hangat bersuhu $39^{\circ} \mathrm{C}$ yang disimpan pada termos nasi plastik masih dapat digunakan selama hampir 5 jam dan berdampak terhadap pencegahan hipotermi dan komplikasinya.

\section{Kesimpulan}

Hasil dari penelitian yaitu enam botol cairan ringer laktat $500 \mathrm{ml}$ yang di simpan di dalam satu termos nasi berukuran 14 liter dan enam botol cairan normal saline $0,9 \% 500 \mathrm{ml}$ yang disimpan di dalam termos nasi berukuran 14 liter dipaparkan suhu ruang 25 
$\pm 1{ }^{\circ} \mathrm{C}$ selama 6 jam adalah adanya perbedaan signifikan antara perubahan suhu cairan ringer laktat dan perubahan suhu normal saline $0,9 \%$.Perubahan suhu enam botol cairan ringer laktat adalah menurun sebesar 4,5 - 4,8 ${ }^{\circ} \mathrm{C}$. Perubahan suhu enam botol normal saline $0,9 \%$ adalah menurun sebesar $4,2-4,5^{\circ} \mathrm{C}$.

Hasil penelitian adalah termos nasi bisa digunakan untuk alat penyimpanan cairan kristaloid ringer laktat dan normal saline $0,9 \%$ yang telah dihangatkan dan berfungsi dapat memperlambat penurunan suhu. Hasil dari penelitian ini diharapkan dapat menjadi acuan sebagai penggunaan termos dalam keadaan tertentu, contohnya pada keadaan bencana yang terdapat pasien dengan kasus syok hemoragik. Dalam keadaan bencana ada beberapa hal yang memungkinkan tempat tersebut terputus daya listriknya. Ketika ingin memberikan resusitasi cairan yang hangat harus dihangatkan di tempat yang memiliki daya listrik, karena alat penghangat perlu daya listrik. Selama perjalanan menuju tempat pasien, termos dapat menjadi media penyimpanan cairan infus hangat tersebut. Hal yang di atas juga dapat diaplikasikan pada rujukan pasien dengan syok hemoragik yang memerlukan perjalanan menuju rumah sakit rujukan selama \pm 5 jam.

\section{Ucapan Terima Kasih}

Terima kasih kepada kedua orang tua dan semua pihak yang telah terlibat dalam penelitian ini terutama pada bapak Abdurrahman Wahid, Ns. M. Kep., Tina Handayani Nasution, Ns., M. Kep., Iwan Sugriwan, M.Si; Dr. Ichsan Ridwan, M. Kom., Gia Eka Negara, S. Si, Ifa Hafifah, Ns., M. Kep., Herry Setiawan, Ns., M. Kep., Nur Azizah, S. Kep., Abu Qasim Rahmadi, S. Kep., Barkatur Rahmaniyah, S. Kep., Rifda Nur Achriana Arif, S. Kep., Helna Fitriana., S. Kep., Nurfiqri Ilham Z., S. Kep.

\section{Referensi}

Agus D, Aryana I G N W. (2017). Gambaran Karakteristik Pasien Fraktur Femur akibat Kecelakaan Lalu Lintas pada Orang Dewasa di Rumah Sakit Umum
Pusat Sanglah Denpasar Tahun 2013. E-Journal Medika Udayana, 6(5): 1-4.

Aldo Y, Nova E S. (2015). Hubungan Waktu Tanggap Perawat dalam Penanganan Pasien Fraktur Terbuka dengan Resiko Terjadinya Syok Hipovolemik di IGD RSUD Dr.Achmad Mochtar Bukit Tinggi Tahun 2015. Jurnal Kesehatan Perintis , 2(2): 107-116.

Anwar F. (2017). Ketika Tubuh Kehilangan Darah, Hal Ini yang Akan Terjadi. Retrieved September 18, 2019, from Detik https://health.detik.com/

Asnawati, Suliyanah, Rohmawati L. (2019). Panduan Praktikum Termodinamika. Surabaya: JDS.

Budhyowati M Y N, Jefrey I. Kindangen J I, Aristotulus E. Tungka A E. (2016). Analisis Faktor-Faktor yang Mempengaruhi Beban Penyejukan pada Bangunan yang Menggunakan Sistem Pengkondisian Udara (Studi kasus Gedung Kantor Pusat Politeknik Negeri Manado). Jurnal Arsitektur, 5(1): 116-126.

Cahyono T. (2017). Penyehat Udara. Yogyakarta: ANDI.

Hall JE. (2011). Guyton and Hall: Buku Ajar Fisiologi Kedokteran. Amerika Serikat: Elsevier.

Harahap, anggita M, Rudi K, Ezra O. (2014). Angka Kejadian Hipotermia dan Lama Perawatan di Ruang Pemulihan pada Pasien Geriatri Pasca Operasi Elektif Bulan Oktober 2011-Maret 2012 di Rumah Sakit DR Hasan Sadikin Bandung. Jurnal Anastesi Peioperatif , 2(1): 36-44.

Hardoko E. (2018). WHO: Tiap 24 Detik Satu Orang Tewas akibat Kecelakaan Lalu Lintas. Retrieved September 18, 2019, from Kompas: https://international.kompas.com

Haynes, William $\mathrm{M}$, et al. (2011). CRC Handbook of Chemistry and Physics. Florida: CRC Press.

Hildebrand F, et al. (2014). Relevance of Induced and Accidental Hypothermia after Trauma-Haemorrhage-What do We Know from Experimental Models 
in Pigs? Intensive Care Medicine, 2(16): 1-14.

Jane L, Ian D N. (2016). Fluid Management 2016: Surgery 342. Elsevier.

Lewis S R, Pritchard M W, Evans D J W, Butler A R, Alderson P, Smith A F, Roberts I. (2018). Colloids versus Crystaloids for Fluid Resuscitation in Critically ill People. Amerika: Cochrane Library.

Makmur, Suparman. (2018). Manajemen Pendidikan. Makassar: Aksara Timur.

Mane A S. (2017). Fluid Resuscitation: Ringer Lactate Versus Normal Saline-A clinical Study. International Journal of Contemporary Medical Research, 4(11): 2454-7379.

Marscella, Fitri A. (2017). Pengembangan Alat Peraga Fisika Sederhana Berupa Termoskop dan Kipas Angin untuk Pembelajaran Termodinamika. Lampung: Universitas Islam Negeri (UIN) Raden Intan Lampung.

Mommpen P, Zeckey C, Frink M, Krettek C, Hildebrand F. (2012). Akzidentelle Hypothermie beim Polytrauma. Zentralbl Chir, 137(3): 264-269.

NANDA. (2015). Diagnosis Keperawatan Definisi \& Klasifikasi 2015-2017. Jakarta: EGC.

Nursalam. (2016). Manajemen Keperawatan (Aplikasi dalam Praktik Keperawatan Profesional). Jakarta: Salemba Medika.

Putri Laili Mei Ari,et al. (2017). Pengaruh Konsentrasi Larutan terhadap Laju Kenaikan Suhu Larutan. Jurnal Pembelajaran Fisika , 6(2): 147-153.

Singleton W, et al. (2017). An Analysis of The Temperature Change in Warmed Intravenous Fluids During Administration in Cold Environments. Air Medical Journal, 36(3): 127-130.

Stewart R M. (2018). Advanced Trauma Life Support Tenth Edition. USA: The Committee on Trauma.

Supu I, Usman B, Basri S, Sunarmi. (2016). Pengaruh Suhu terhadap Perpindahan Panas pada Material yang Berbeda. Jurnal Dinamik, 7(1): 62-73.

Tanaka C, Wiargitha K, Golden N. (2018). Koagulopati Dini sebagai Faktor Resiko Mortalitas pada Trauma
Abdomen di Rumah Sakit Sanglah Periode Tahun 2015-2016. Medicina, 49(3): 382-387.

Wirawan I M C. (2017). Berbagai Tips Hidup Sehat dengan Cara Sederhan . Jakarta: Noura Books.

Yanala U R, Johanning J M, Pipinos I I, High R R, Larsen G, Velander W H, Carlson M A. (2018). Fluid Administration Rate for Uncontrolled Intra Abdominal Hemorrhage in Swine. Plos One, 13(11): 1-13.

Yulkifli, Usmeldi, Yohandri, Anggreini. (2017). Pegembangan Thermobalance Digital Berbasis Teknologi Sensor dan Lembar Kerja Peserta Didik Menggunakan Model Research Based Learning. Jurnal Pengajaran Matematika dan Ilmu Pengetahuan Alam, 22(1): 1-5. 